\title{
Studies in organic archaeometry I: identification of the prehistoric adhesive used by the "Tyrolean Iceman" to fix his weapons ${ }^{1}$
}

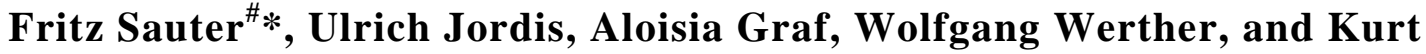 \\ Varmuza
}

Vienna University of Technology, Getreidemarkt 9, A-1060 Vienna, Austria E-mail:fsauter@pop.tuwien.ac.at

Knowing about his many interests I dedicate this paper to my old friend Otto Meth-Cohn on the occasion of his $65^{\text {th }}$ birthday

(received 11 Aug 00; accepted 03 Oct 00; published on the web 11 Oct 00)

\begin{abstract}
The weapons of the glacier mummy of the chalcolithic "Man from the Hauslabjoch" (i.e. the "Tyrolean Iceman", nicknamed "Oetzi") contained traces of organic adhesives, obviously used to fix parts of his weapons (i.e., the flintstone arrowheads and the copper hatchet) to their respective shafts.

In order to prove whether or not these adhesives might be birch bark pitches similar to some other organic materials found in Central and Northern Europe, model pitches were prepared from a large number of different trees and a sequence of analytical methods was developed to differentiate between the different species of trees.

The crucial features of this analytical sequence consisted in the isolation of a characteristic terpene fraction by Kugelrohr distillation, followed by GC/MS analysis and by application of chemometrics to improve the interpretation of the GC/MS results.

By this methodology it could be shown that Oetzi's weapons were glued by means of birch bark pitch. To prepare this, pyrolysis of the bark of the birch (betula pendula = betula verrucosa) obviously gave a tar, which on heating was converted into the thermoplastic pitch.
\end{abstract}

Keywords: prehistoric adhesive, birch bark pitch, triterpenes, betulin, chalcolithic weapons, Tyrolean glacier mummy ("Tyrolean Iceman“) 


\section{Introduction}

In 1991 the frozen mummy of a man was found by chance in a slightly retreating glacier of the Tyrolean Alps close to the frontier between Austria and Italy. Although the find should exactly be called "the man from the Hauslabjoch“2 (according to the geographical site), he was immediately named "the Tyrolean Iceman" or simply "Oetzi", (in German: Ötzi), nicknamed according to the torrent Ötz having there its origin.

According to the characteristic objects found with him he obviously lived some 5200 years before our days, thus belonging to the Late Neolithic (Chalcolithic). This old age as well as the relatively good preservation due to the frozen state made Oetzi as well as the accompanying finds a favoured object of archaeological research ${ }^{2}$.

Among the many accompanying objects found near to Oetzi were two arrows with flintstone arrowheads and a copper hatchet; in all three objects the stone or metal part was fixed to appropriate wooden shafts by means of an organic agglutinant. When publishing our earlier studies about this material we came to the conclusion ${ }^{3}$ that the substance in question is a betulin-containing pitch, i.e., the product of pyrolysis of wood or bark taken from a tree belonging to the family of birch-like trees (betulaceae), maybe even taken from the birch (betula) itself. These results were in analogy to some other ones obtained already earlier by us $^{4}$ and by other researchers ${ }^{5}$ when studying (by a variety of methods) prehistoric organic materials found at many different sites in Central and Northern Europe.

The present study should not only confirm our earlier results but aimed at additional and more specified information.

The method which we developed for this purpose was the following: "Model pitches" were prepared from a large number of different trees. Several archaeological pitches already analyzed (coming from Denmark, Austria and Hungary, dated from Late Neolithic to Early Iron Age) were also used for comparison.

From all these samples (from archaeological as well as from model pitches)

the significant triterpene fraction was "cut out" by Kugelrohr distillation, the product thus obtained was prepurified and analyzed by GC/MS.

Finally the data thus obtained were studied by chemometric methods. 


\section{Results and Discussion}

\section{Preliminary GC/MS results}

Figure 1 shows the gas chromatogram (total ion current from a GC/MS analysis) of a pitch sample used as adhesive at Oetzi's weapons.

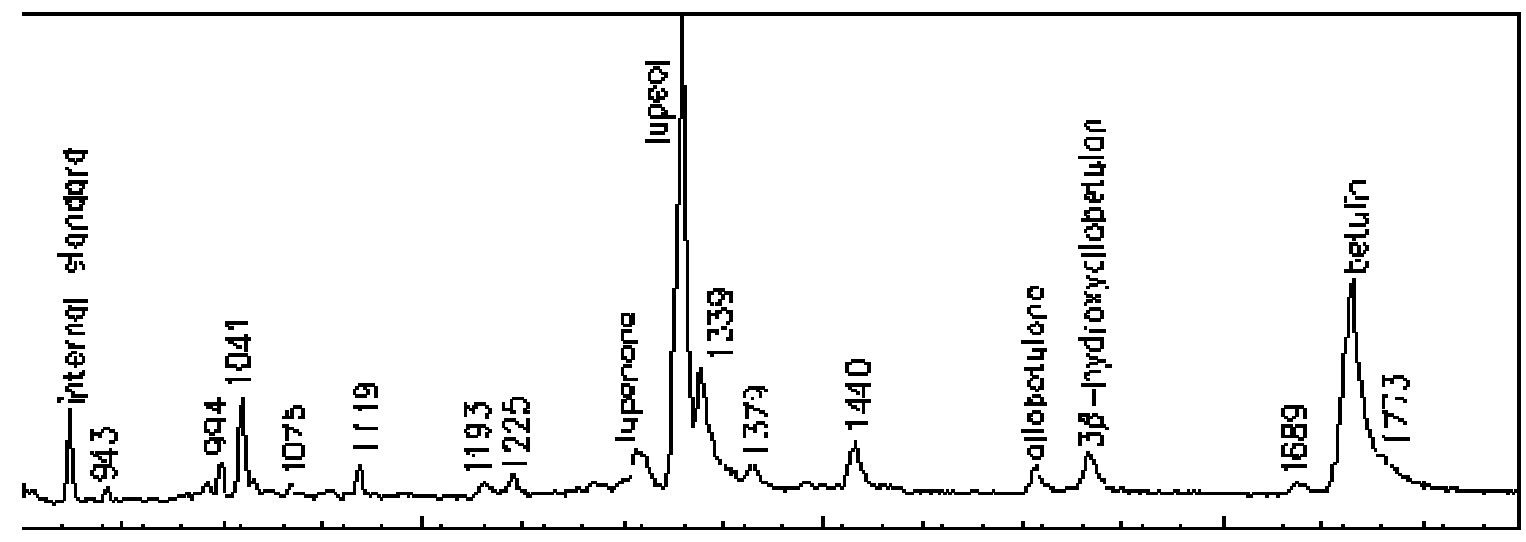

Figure 1. Preliminary GC/MS studies: analysis of the pitch used as adhesive to fix Oetzi’s copper hatchet.

As both the two other samples taken from the adhesives of Oetzi's weapons gave practically identical GC results, it can already be concludedthat all the three studied adhesives which Oetzi has used to fix his weapons were identical, hat the triterpenes usually found in prehistoric pitches are occurring here as well, hat some triterpenes like lupeol and betulin are occurring, which are always found in pitches prepared from the bark of the birch (betula alba), while they are never found in pitches prepared from many other trees such as ash (fraxinus), maple (acer), elm (ulmus) or oak (quercus), that betulin is occurring in such high quantities that only bark of the birch (betula) can be assumed to have been the raw material from which this prehistoric pitch was prepared in Oetzi's time, as all the other genera of the birch-like family (betulaceae) are containing betulin only in small quantities. 
From all this it can already be concluded that the studied material which Oetzi has used as adhesives to fix the stone and copper parts of his weapons to their respective shaft were prepared by pyrolysis from bark of the birch (betula). To make these results even more unequivocal, chemometric methods were applied with the intention also to allow a distinction within the members of the birch-like family (betulaceae).

\section{Chemometric studies}

Differentiation between birches and "non-birches" (also including "nonbetulaceae“6)

Linear discriminant analysis was applied to test whether birch samples can be separated from samples originating from other trees by an objective chemometric method or not. The result is shown in Figure 2

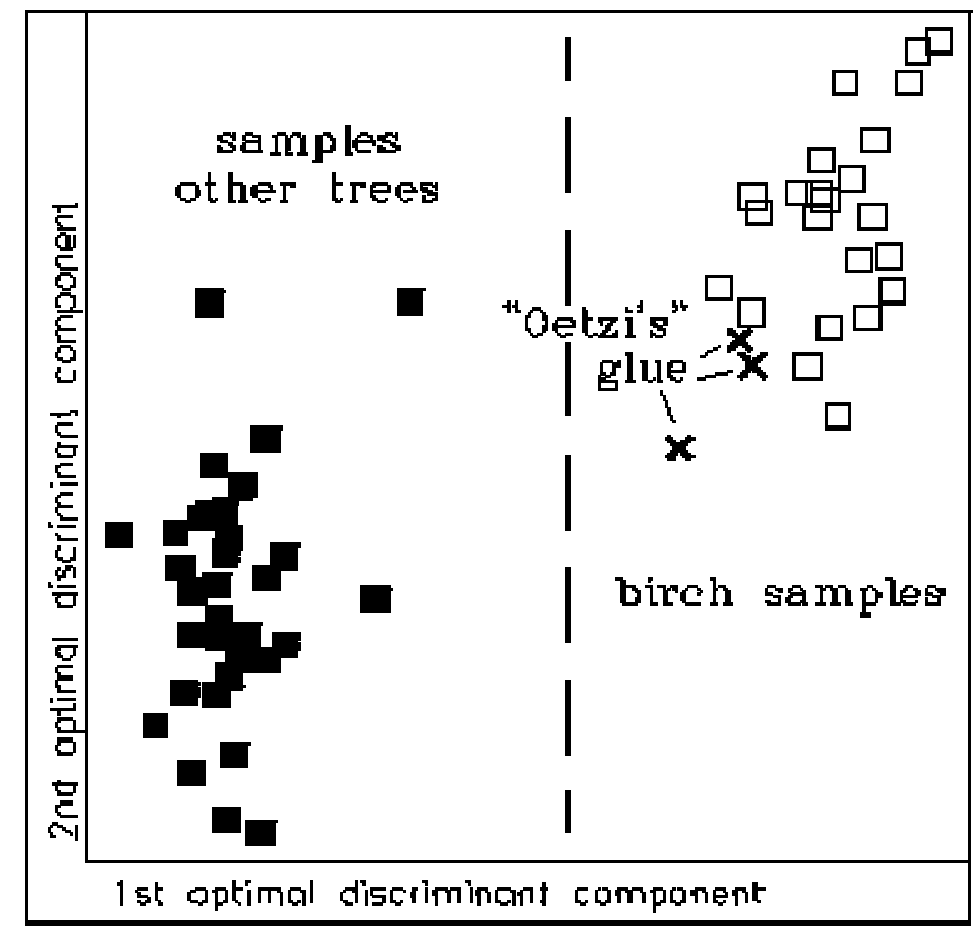

Figure 2. LDA differentiates between birches and other trees.

The plot depicts class 1: 23 (distilled) pitches prepared from the bark of the birch (under differing conditions), class 2: 33 (distilled) pitches prepared 
from wood and/or bark of other trees, and the 3 (distilled) prehistoric adhesives taken from Oetzi's weapons (symbolized by X).

This result was checked by a "Leave-a-quarter-out" test to minimize too optimistic conclusions based on artifact separations, but no misclassification was found. The obvious result: the three analyzed adhesives used by Oetzi can be assigned to the bark of the birch (betula).

\section{Differentiation between the birch and "non-birches" (within the family "betulaceae")}

This differentiation is dealing only with different members of the betulin containing botanical family of birch-like trees (betulaceae), within which only the bark of the birch (betula) contains $\mathrm{l}$ a $\mathrm{r}$ g e quantities of betulin. Application of PLS discriminant mapping allowed a good separation of the four considered classes of samples. The obvious result is that the three samples in question can be attributed to the birch.

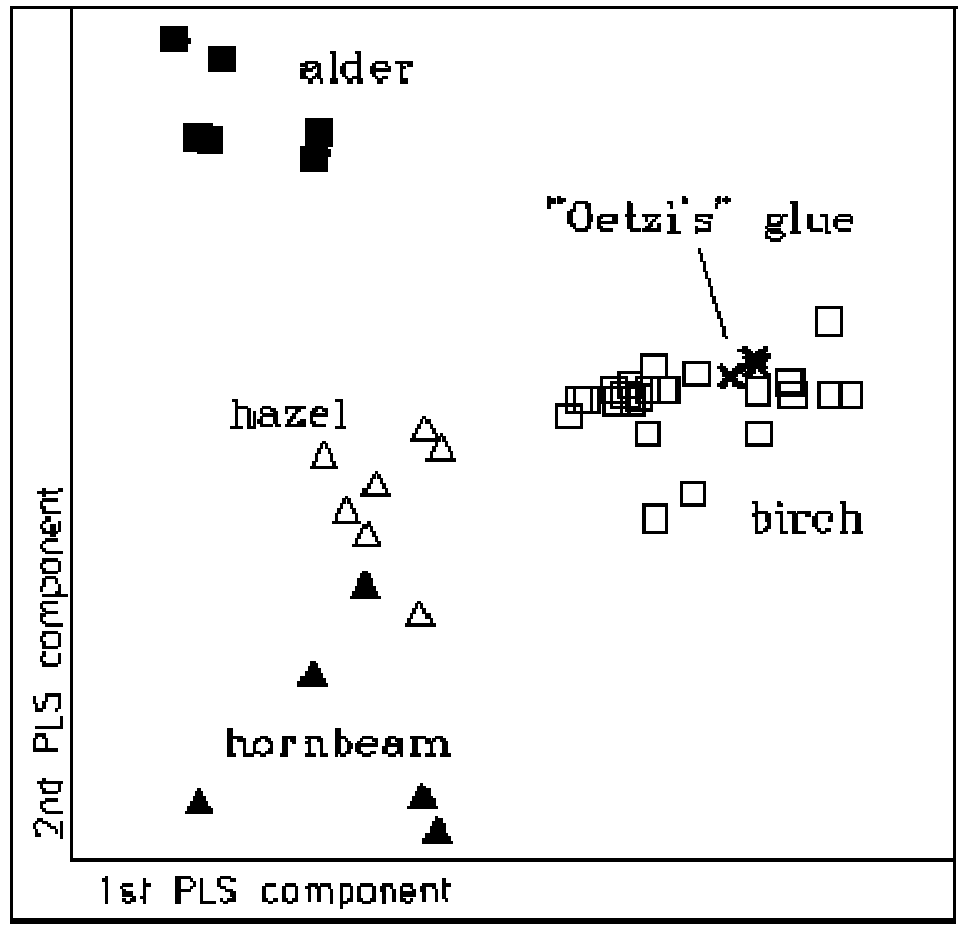

Figure 3. PLS discriminant mapping. 
Two of the Oetzi samples symbolized by $\mathrm{X}$ are overlapping each other.

\section{Experimental Section}

\section{Archaeological samples}

Apart from some prehistoric pitches which we had already analyzed earlier (3 from Denmark, 14 from various sites in Lower Austria and 3 from Upper Austria, all of which were used for comparison) three samples stemming from the Oetzi trouve were studied:

traces of the agglutinant taken from the copper hatchet 91/112 \# traces from the agglutinant found on a flintstone arrowhead 91/112 (28) ${ }^{\#}$ traces from the agglutinant found on the arrowhead of arrow no.12 91/121 $\left(^{\#}=\right.$ inventory of the Römisch-Germanisches Zentralmuseum Mainz, Germany)

\section{Preparation of the "model pitches"} Preparation of pitches by pyrolysis of wood or bark (in particular for preparing larger quantities of pitch)

Ca. $60 \mathrm{~g}$ of the natural material (e.g. birch bark) were cut to small pieces, dried for 5-6 days at $70^{\circ} \mathrm{C}$ and pyrolyzed in a vertically mounted glass tube (ca. 30-35 cm length, sealed on top, narrowed and closed with some glass wool at the bottom) by electric heating from outside (thermostat, measuring temp. inside the glass tube: temp. raised from room temp. to ca. $500^{\circ} \mathrm{C}$ within 80 min., $1 \mathrm{hr}$. kept at $500^{\circ} \mathrm{C}$ ). Beginning at ca. $260^{\circ} \mathrm{C}$ a viscous oil was dropping down through a funnel into a flask, becoming darker at ca. $280^{\circ} \mathrm{C}$, while beginning with ca. $300^{\circ} \mathrm{C}$ the product thus obtained was a brown, viscous oil, solidifying on cooling (yield: ca. 6 g), which was Kugelrohr distilled to isolate the terpene fraction as described below.

\section{Shortened procedure combining pyrolysis + distillation (used for wood/bark samples)}

(particularly applied for preparation of small quantities of tars)

Ca. 1-4 g dried bark or wood were slowly (12-15 min.) heated in a Kugelrohr up to $300^{\circ} \mathrm{C}$ under reduced pressure (22-26 mbar, ca. $45-55 \mathrm{~min}$ ) and kept at $300^{\circ} \mathrm{C}$ (temp. measured outside) for $15 \mathrm{~min}$., yielding a viscous oil as above. 


\section{Treatment of the archaeological samples}

Out of ca. 350-980 $\mathrm{mg}$ of the prehistoric pitch (according to availability; in special cases only ca. $10 \mathrm{mg}$ ) the characteristic terpene fraction was isolated by Kugelrohr distillation as described above (c.f. 2.2.).

\section{Purification of the products obtained by distillation}

Before being used for GC/MS analysis the oily products obtained by distillation were purified by solid phase extraction: A solution in THF (p.a., FLUKA 87368; $1 \mathrm{ml}$ for $10 \mathrm{mg}$ distilled oil) was filtered through a Bond Elut Silica column. After washing with some THF the solution was once again filtered through a Bond Elut C18 (ODS) column (washed with MeOH-THF $4: 1)$. The purified solution thus obtained was distilled to dryness $\left(40^{\circ} \mathrm{C}\right.$, under $\mathrm{N}_{2}$ ) and the residue dissolved in THF for GC/MS analysis.

Gas chromatography / mass spectrometry (GC/MS)

For GC/MS analyses a Fractovap 4160 (Carlo-Erba) (30 m "fused silica" capillary column DB-5 Durabond; He: 0.9 bar; temp. program: 45$290^{\circ} \mathrm{C}$ )with on-column injection was used, directly coupled to a mass spectrometer Finnigan MAT 8230 (70 eV in El mode for $\mathrm{m} / \mathrm{z}$ 45-750; resolution 1000; $1.3 \mathrm{sec} / \mathrm{scan})$.

\section{Chemometrics}

Although - following our methodology - GC/MS and chemometric studies had only to deal with the "terpene fraction", only a small number of substances could be identified by MS or by comparison of retention times. Therefore the MS peak patterns were used to characterize the mixture components present in different species of trees.

Since the gas chromatograms of pitches prepared from conifers proved to be significantly different from those prepared from deciduous trees, chemometric studies could be restricted to the latter ones. The concentrations of 50 most characteristic substances have been used for multivariate data analysis $^{6}$ by linear discriminant analysis (LDA) and partial least squares (PLS) discriminant mapping. 


\section{Conclusions}

The adhesives used by Oetzi, the "Tyrolean Iceman", to fix his flintstone arrowheads and his copper hatchet to their respective shafts is a pitch, prepared by heating a tar, which was obtained by pyrolysis of birch bark. As only the bark of the common birch tree (betula pendula = betula verrucosa) contains correspondingly large quantities of betulin, it seems obvious that this was used in Oetzi's time as the starting material to prepare the desired agglutinant.

The origin of this material is in accordance with many other prehistoric pitches which were used in Northern and Central Europe as polyfunctional material (e.g. used for ancient repair work of broken pottery, or as coating of potteries, etc.).

The fact that the results obtained from the Oetzi samples are in full correspondence with "pure" model pitches prepared exclusively from birch bark allows the conclusion that also in prehistoric times "pure" birch bark was the raw material used.

The question by which technique the desired pitch might have been prepared in prehistoric times can be answered from the chemical point of view only by hypothetical assumptions, but two observations should be given from our side:

*when raw material had to be collected by us for preparing the model pitches it soon turned out that larger quantities of birch bark can be recovered by far easier from a birch which was cut down ca. one year ago, and

*the fact that in prehistoric pitches some "thermic degradation markers", e.g. lupenon (as depicted in fig.1) and lupadiene are occurring only in very low quantities could indicate that the prehistoric production process was less vigorous as compared with our laboratory technique.

\section{Acknowledgments}

The authors would like to thank to Prof. Dr. Markus Egg (RömischGermanisches Zentralmuseum Mainz), who made the pitch samples available to us. 
We also express our thanks to Dr. E. W. H. Hayek, who did some parts of his Ph.D.thesis in this field, for his valuable contributions.

The present work was partially sponsored by the Austrian Funds for Scientific Research (FWF, Fonds zur Förderung der wissenschaftlichen Forschung).

\section{References and Notes}

An extended German version of the present paper will be published in the next volume of "Der Mann im Eis", edited by the University of Innsbruck, Austria

Frank Hoepfel, Werner Platzer and Konrad Spindler (editors): Der Mann im Eis, vol.1, 1992 (Publications of the University of Innsbruck, no. 187)

F. Sauter, U. Jordis und E. Hayek: in Frank Hoepfel, Werner Platzer and Konrad Spindler (editors): Chemische Untersuchungen der Kittschäftungsmaterialien; Der Mann im Eis, vol.1, 1992, 435-441 (Publications of the University of Innsbruck, no. 187)

Some of our earlier papers dealing with analytical studies of prehistoric pitches and pitch components:

1. Sauter, F. Chemische Untersuchung von Harzüberzügen auf hallstattzeitlicher Keramik Archaeologia Austriaca; 1967, 41, p 25-36.

2. F. Sauter and U. Jordis (cooperation in botany: F. Wurst):Neue chemische Untersuchungen zur Frage der "Harzüberzüge" auf prähistorischer Keramik FIST (Forschungen in Stillfried) 4, 147-161 (und Tafeln 56-62) (1980) within the series: Veröffentlichungen der Österr.Arbeitsgemeinsch. für Ur- und Frühgeschichte vol.III/XIV (1974)

3. F. Sauter, E. W.H. Hayek, W. Moche and U. Jordis: Betulin aus archäologischem Schwelteer (Identification of Betulin in Archaeological Tar) Z. Naturforsch. 42c, 1151-1152 (1987)

4. E. W. H. Hayek, U. Jordis, W. Moche and F. Sauter: A Bicentennial of BetulinReview Article No 46 in: Phytochemistry, .28, No.9, pp. 22292242, 1989

5. E. W. H. Hayek, W. Moche, U. Jordis, P. Krenmayr and F. Sauter: Chemische Analyse von drei bronzezeitlichen Pechfunden aus Dänemark Teil III (S.215-218) in: C. J. Becker: Ein ungewöhnliches "Depot" der 
jüngeren Bronzezeit von Spald, Westjütland Acta Archaeologica (Kopenhagen) 60 - 1989, 193-227 (Munksgaard 1990)

6. E. W. H. Hayek, P Krenmayr, H Lohninger, U. Jordis, W. Moche and F.Sauter:Identification of Archaeological and Recent Wood Tar Piches Using Gas Chromatography/Mass Spectrometry and Pattern Recognition Analytical Chemistry 62, 2038-2043 (1990)

7. E. W. H. Hayek, P. Krenmayr, H. Lohninger, U. Jordis, F. Sauter and W. Moche: GC/MS and chemometrics in archaeometry: Investigation of glue on copper-age arrowheads; Fresenius J. Anal. Chem. 340, 153-156 (1991)

8. F. Sauter, U. Jordis and E. Hayek: Chemische Untersuchungen der Kittschäftungsmaterialien (cf: lit. 3)

9. Fritz Sauter, Ulrich Jordis and Erich W.H.Hayek: Chemische Untersuchungen eines eigenartigen organischen Materials aus einer späturnenfelderzeitlichen Opfergrube in Stillfried an der March, NÖ.: Verändertes Birkenpech in bisher unbekannter Form FIST (Forschungen in Stillfried) 9/10, 75-88 1990-2 (published 1996)

10. U. Jordis, F. Sauter, K. Varmuza, W. Werther, A. Graf and E. Hayek: Birkenrindenpech als Kittschäftungsmaterial auf "Ötzi's Pfeilspitzen”; Symposium "Archäometrie und Denkmalpflege“ (Vienna 1997),Vol.of Abstracts p. 178-179

11. F. Sauter, U. Jordis, K. Varmuza, W. Werther, A. Graf und E. Hayek: Pyrolysiertes Birkenrindenpech als Opfergabe; Symposium “Archäometrie und Denkmalpflege“ (Vienna 1997), Vol.of Abstracts p. 259

12. Fritz Sauter, Ulrich Jordis and Erich W.H.Hayek: Eine Untersuchungsmethode für prähistorische Holzpeche zur Bestimmung der verwendeten Baumart; Proceedings of the First International Symposium on Wood Tar and Pitch (Piskupin 1993), State Archaeological Museum in Warsaw (Herausg. W. Brzezinski und W. Piotrowski), [published] 1997, p. 213-217

13. C. Hametner, J. Fröhlich, F. Sauter and A. Graf: Archaeometric Investigations of Prehistoric Pitches and Tars by ${ }^{13} \mathrm{C}-\mathrm{NMR}$ Spectroscopy; Abstracts of the 13th Meeting of the Central European NMR Discussion Groups (27-29 April, 1998, Valtice, Czech Republic) 
14. W. Werther, K. Varmuza, E. Hayek, F. Sauter, U. Jordis and A. Graf: The Tyrolean Iceman: Origin of Wood Pitches Used as Adhesives on Prehistoric Tools and Weapons; Abstracts des Second International Chemometrics Research Meeting (24-28 May, 1998, Veldhoven/Eindhoven, $N L$ ), p. 51

15. W. Werther, K. Varmuza, E. Hayek, F. Sauter, U. Jordis and A. Graf: Investigation of the Origin of Wood Pitches Found with the Tyrolean Iceman by Applying GC /MS / Chemometrics; Abstracts of the 5th International Symposium Chromatography \& Hyphenated Techniques (October 5-9, 1998, Bled, Slovenia), p.160

16. J. Fröhlich, C. Hametner, F. Sauter und A. Graf: Identifizierung von Betulin in prähistorischen Pechfunden mittels ${ }^{13} \mathrm{C}$-NMR-Spektroskopie Berliner Beiträge zur Archäometrie 16, 241-250 (1999)

17. Some papers published by other research teams dealing with analytical studies of prehistoric pitches and pitch components (using alternative analytical methods): c.f. also review article: . Weiner: European Pre- and Protohistoric Tar and Pitch: Contribution to the History of Research 1720-1999, Acta Achaeometrica, vol.1 (Coburg 1999)

18. D. Hadzi and F. Cvek: Smolni kit in premaz za zare (resinous putty and peint on urns) Arheološki vestnik 27, 128-134 (1976)

19. H. Funke: Chemisch-analytische Untersuchungen verschiedener archäologischer Funde Ph.D Thesis (University of Hamburg 1969)

20. K. Ukkonen and V. Erä: Birch Bark Extractives Kemia-Kemi 5, 217-220 (1979)

21. R. C. A. Rottländer: Naturwissenschaftliche Methoden in der Archäologie Achaeologica Venatoria 6, Tübingen (1983)

22. C. Heron, R. P.Evershed, B. Chapman \& A. M. Pollard: Glue, Disinfectant and 'Chewing Gum' in Prehistory Archaeological sciences 1989, 325-331 (eds. P. Budd et al., Oxbow Books, Oxford)

23. Didier Binder, Guy Bougeois, Françoise Benoist et Christiane Vitry: Identification de brai de bouleau (Betula) dans le neolithique de Giribaldi (Nice, France) par la spectrometrie de masse Revue d'Archéométrie 14, 37-42 (1990)

24. S. Charters, R. P. Evershed, L. J. Goad, C. Heron and P. Blinkhorn: Identification of an Adhesive Used to Repair a Roman Jar Archaeometry 35, 91-101 (1993) 
25. M.Regert, Chr. Rolando: Archéologie des résidus organique - De la chimie analytique à l'archéologie: un état de la question Techne 3, 118128 (1996)

26. K. Ruthenberg: Fingerprint Characterization of Ancient Tar and Pitch with Gas Chromatography / Mass Spectrometry in: E. Pernicka and G. A. Wagner (eds.)Archaeometry '90, 505-511 (Berlin)

27. K. Ruthenberg and A. Kurzweil: Infrarotspektren zur Charakterisierung von Teer und Pech Chemie in Labor und Biotechnik 45, 4-7 (1994)

28. K. Ruthenberg Historical Development and Comparison of Analytical Methods for the Identification of Tars and Pitches Proceedings of the First International Symposium on Wood Tar and Pitch (Piskupin 1993), State Archaeological Museum in Warsaw (Herausg. W. Brzezinski und W. Piotrowski), [published] 1997, S. 173-179

29. Jerzy J:Langer: Identification of the Neolithic Wood Tar Proceedings of the First International Symposium on Wood Tar and Pitch (Piskupin 1993), State Archaeological Museum in Warsaw (Herausg. W. Brzezinski und W. Piotrowski), [published] 1997, S. 193-196

30. Anthony Crawshaw:Low Technology Analyses of Tars and Pitches Proceedings of the First International Symposium on Wood Tar and Pitch (Piskupin 1993), State Archaeological Museum in Warsaw (Herausg. W. Brzezinski und W. Piotrowski),[published] 1997, S. 197202

31. Kath M. Bonfield, Carl Heron and Nadia Nemcek: The Chemical Characterization of Wood Tars in Prehistoric Europe: A Case Study from the Neolithic of Southern Germany Proceedings of the First International Symposium on Wood Tar and Pitch (Piskupin 1993), State Archaeological Museum in Warsaw (Herausg. W. Brzezinski und W. Piotrowski),[published] 1997, S. 203-212

32. J. Koller and U. Baumer: Analyse einer Kittprobe aus dem Griff des Messers von Xanthen-Wardt Acta Praehistorica et Archaeologica 25, 129-131 (1993)

33. J. Koller and U. Baumer: Die Untersuchung von prähistorischen Birkenpechfunden mittels GC und GC/MS Symposium "Archäometrie und Denkmalpflege“ (Vienna 1997),Abstracts p.175-177 
34. J. M. Grünberg, H. Graetsch, u. Baumer and J. Koller: Untersuchung der mittelpaläolithischen „Harzreste“ von Königsaue, Ldkr. AscherslebenStraßfurt

35. Varmuza, K. In The encyclopedia of computational chemistry (Schleyer P.v.R., Allinger N.L., Clark T., Gasteiger J., Kollman P.A., Schaefer III.H.F, Schreiner P.R., eds.) Vol. 1, p. 346. Wiley, Chichester, 1998. Chemometrics - Multivariate view on chemical problems. 